\title{
Efficiency of Centella asiatica (Gotu kola) leaf meal as feed additive in broiler chicken diet
}

Ajayi, O. A., Olumide, M. D., Chioma, G. O. and Ayodele, A. D. Department of Agriculture and Industrial Technology, Babcock University, Ilishan Remo, Ogun State. Nigeria.

Corresponding author: opeyemi8591@gmail.com; +2348067905175

\section{Abstract}

The use of conventional supplements as feed additives has been criticized for their potential negative impact on the food chain hence, the need for viable organic alternatives. Centella asiatica has been found to contain essential phytochemicals. This study was therefore carried out to evaluate the utilization of dried Centella asiatica leaf meal (CALM) as phytogenic feed additive in broiler chicken diet. A total of 180, one-day-old Arbor acre broiler chicks were randomly allocated to six dietary treatment groups with thirty birds, at three replicates of ten chicks per replicate. Experimental diets included control basal diet + 0\% CALM (T1), basal diet + antibiotics (T2). T3, T4, T5 and T6 were basal diet $+3 \%, 4 \%$, $5 \%$ and $6 \%$ CALM, respectively. Completely randomized design was used and feeding trial was carried out for 49 days. Parameters measured were growth performance and carcass characteristics. All data were subjected to analysis of variance using Statistical Package for Social Sciences (version 21) while treatments means were separated using Duncan's multiple range test at $P \geq 0.05$ level of significance. There were significant differences in final live weight, body weight gain and feed conversion ratio. Birds fed with 4\% CALM had the highest weight gain $(1,683.30 \mathrm{~g})$ and feed intakes $(3,295.30 \mathrm{~g})$, while T3 had the lowest weight gain $(1,446.70 .30 \mathrm{~g})$ and feed intake $(3,107.80 \mathrm{~g})$. The breast cut showed significant $(P<0.05)$ variation across the treatment with treatment T2 having the largest value of $31.9 \%$ and lowest value of $26.0 \%$ was in obtained in T3, thigh showed highest value in T5 and lowest value in T4. Gizzard values obtained in this finding showed significant $(P<0.05)$ difference value ranged from 1.8-2.6\% the highest value was obtained in T3 and lowest value in control diet. It can be concluded that the inclusion of Centella asiatica in the diets of broiler chicken has no detrimental effect on the performance characteristics of the experimental birds but improved the average body weight, feed conversion ratio and livability of the birds at 4\% level of inclusion.

Keywords: Centella asiatica, Performance, Carcass, Broilers, Additives.

\section{Introduction}

Feed is a major component affecting net return from the poultry business, because $80 \%$ of the total expenditure is on feed purchase (Qureshi,1991). To ensure more net return and to minimize high expenditure on feed which is the main challenge, many research strategies have been practiced such as introducing feed supplements and feed additives (Perves, 1992). Due to intensification of poultry production in the last decade, varieties of non- nutritive feed additives have been used in poultry production to improve the overall performance of birds. Antibiotics growth promoter (AGP) have been included in poultry diets to promote growth, health and to maximize the genetic potentials of modern poultry. (Bozkurt et al., 2008). However, the presence of residue of antibiotics in meat and meat products meant for human consumption and the development of drug resistant microorganisms in human has brought about the 


\section{Efficiency of Centella asiatica (Gotu kola) leaf meal as feed additive}

search for alternative plant extracts as antibiotics and growth promoters (Denli et al., 2003). Cross et al. (2003) and Lewis et al. (2003) identified several beneficial chemical components in medicinal plants which play an important role in improving production and immune system of birds against diseases and have strong medicinal and could be effectively utilized as natural growth promoter to replace antibiotics and other synthetic feed additives. Many types of feed additives are being used in broiler rations to improve its performance; spices are very common additives in broiler diets (Zhang et al., 2009). However, Feed additives are added to the diets of broilers to improve its production performance by increasing growth rate, feed conversion efficiency and greater livability in poultry birds. The environment of man is endowed with plants and fruits which are used as sources of spices in food, stimulants and some micro nutrients. These plants or spice include garlic (Allium sativum), ginger (Zingiber officinale) and gotu kola (Centella asiatica) Centella asiatica L. (Gotu Kola) Urban is a tropical medicinal plant from Apiaceae family native to Southeast Asian countries such as India, Sri Lanka, China, Indonesia, and Malaysia as well as South Africa and Madagascar (Jamil et al., 2007). It is native to the warmer regions of both hemispheres. This plant grows wild in damp, shady places up to $7000 \mathrm{ft}$. and can be commonly seen along banks of rivers, streams, ponds, and irrigated fields. It also grows along stone walls or other rocky areas at elevation of approximately $2000 \mathrm{ft}$. The nutritional value of C. asiatica is attributed to its richness in carotenoids and vitamins $\mathrm{C}$ and $\mathrm{B}$ complex. The herb is commonly used for children in Sri Lanka in order to combat nutritional deficiency (Cox et al., 1993). C. asiatica is also a traditional green leafy vegetable (GLV) and locally consume it as
"Gotu kola sambola. It is used as a health tonic and processed into cordial drinks and it is available at some markets as a readymade juice (Mohd Ilham, 1998). It is believed that $C$. asiatica herbal tea is a source of antioxidants with many beneficial effects (Huda-Faujan et al., 2007). The objective of this to evaluate the efficiency of dried CALM as phytogenic feed additives for broiler chicken.

\section{Materials and method Experimental site}

The research was carried out at the teaching and research farm. Department of Agriculture and Industrial Technology, Babcock University, Ilishan-Remo, Ogun State Nigeria.

Source and preparation of experimental plant

Centella asiatica plant was harvested from Babcock University farm. The plant was washed, chopped and air dried. The dried material was pulverized into fine powder in a blender and mixed with the feed in varying proportion for experimental study

\section{Experimental design and management}

A total of 180-day-old Arbor acre birds were randomly allocated to six dietary treatment groups with thirty birds, at three replicates of ten chicks per replicate.

\section{Experimental diet}

Basal diet (Control), basal diet + antibiotics, basal diet $+3 \%$ CALM, basal diet $+4 \%$ CALM, basal diet $+5 \%$ CALM and basal diet $+6 \%$ CALM

\section{Data collection}

Data were collected on growth performance (feed intake, changes in body weight, feed conversion ratio and survivability), Carcass characteristics (breast, thigh, drumstick, intestine, gizzard, heart and liver)

Average feed intake/animal $=$

Feed offered $(\mathrm{g})$ - feed leftover $(\mathrm{g})$

Total number of animal in the group 
Ajayi, Olumide, Chioma and Ayodele

Table 1: Gross composition of starter diet containing varying levels of CALM

\begin{tabular}{|c|c|c|c|c|c|c|c|}
\hline Ingredient & $\begin{array}{l}\text { Control } \\
\text { (T1) }\end{array}$ & $\begin{array}{l}\text { T2 } \\
\text { (antibiotics) }\end{array}$ & \multicolumn{2}{|c|}{$\begin{array}{l}\text { (T3) } \\
3 \%(\mathrm{CA})\end{array}$} & $\begin{array}{l}\text { (T4) } \\
4 \%(\mathrm{CA})\end{array}$ & $\begin{array}{l}\text { (T5) } \\
5 \%(\mathrm{CA})\end{array}$ & $\begin{array}{l}\text { (T6) } \\
6 \% \\
(\mathrm{CA}) \\
\end{array}$ \\
\hline Maize & 55.00 & 55.00 & 55.00 & & 55.00 & 55.00 & 55.00 \\
\hline GNC & 20.00 & 20.00 & 20.00 & & 20.00 & 20.00 & 20.00 \\
\hline SBM & 14.30 & 14.30 & 14.30 & & 14.30 & 14.30 & 14.30 \\
\hline Fish meal $(72 \% \mathrm{CP})$ & 3.00 & 3.00 & 3.00 & & 3.00 & 3.00 & 3.00 \\
\hline Wheat offal & 2.00 & 2.00 & 2.00 & & 2.00 & 2.00 & 2.00 \\
\hline Limestone & 1.00 & 1.00 & 1.00 & & 1.00 & 1.00 & 1.00 \\
\hline DCP & 2.00 & 2.00 & 2.00 & & 2.00 & 2.00 & 2.00 \\
\hline $\mathrm{PKC}$ & 2.00 & 2.00 & 2.00 & & 2.00 & 2.00 & 2.00 \\
\hline Common Salt & 0.25 & 0.25 & 0.25 & & 0.25 & 0.25 & 0.25 \\
\hline Methionine & 0.10 & 0.10 & 0.10 & & 0.10 & 0.10 & 0.10 \\
\hline Lysine & 0.10 & 0.10 & 0.10 & & 0.10 & 0.10 & 0.10 \\
\hline Premix & 0.25 & 0.25 & 0.25 & & 0.25 & 0.25 & 0.25 \\
\hline Total & 100 & 100 & 100 & & 100 & 100 & 100 \\
\hline \multicolumn{8}{|l|}{ Determined value } \\
\hline Crude fibre & 3.28 & 3.28 & 3.30 & & 3.31 & 3.32 & 3.33 \\
\hline Crude protein & 22.34 & 22.34 & 22.37 & & 22.39 & 22.40 & 22.41 \\
\hline Ether extract & 3.51 & 3.50 & 3.51 & & 3.52 & 3.32 & 3.55 \\
\hline $\begin{array}{l}\text { Metabolizable energy } \\
(\mathrm{kcal} / \mathrm{kg})\end{array}$ & 2960 & 2960 & 2960 & & 2960 & 2960 & 2960 \\
\hline \multicolumn{8}{|c|}{$\begin{array}{l}\mathrm{GNC}=\text { Groundnut cake } \text { PKC }=\text { Palm kernel cake } \\
\mathrm{DCP}=\text { Dicalcium Phosphate } ; \mathrm{SBM}=\text { Soya bean Meal. }\end{array}$} \\
\hline \multicolumn{8}{|c|}{ Table 2: Gross composition of finisher diet containing varying levels of Centella asiatica } \\
\hline Ingredients & $\begin{array}{l}\mathrm{T} 1 \\
\text { (Control) }\end{array}$ & $\begin{array}{l}\mathrm{T} 2 \\
\text { (antibi }\end{array}$ & tics) & $\begin{array}{l}3 \% \\
(\mathrm{CA})\end{array}$ & $\begin{array}{l}4 \% \\
(\mathrm{CA})\end{array}$ & $\begin{array}{l}5 \% \\
(\mathrm{CA})\end{array}$ & $\begin{array}{l}6 \% \\
(\mathrm{CA})\end{array}$ \\
\hline Maize & 59.00 & 59.00 & & 59.00 & 59.00 & 59.00 & 59.00 \\
\hline GNC & 17.00 & 17.00 & & 17.00 & 17.00 & 17.00 & 17.00 \\
\hline SBM & 8.00 & 8.00 & & 8.00 & 8.00 & 8.00 & 8.00 \\
\hline $\begin{array}{l}\text { Fish meal } \\
(72 \% \mathrm{cp})\end{array}$ & 1.00 & 1.00 & & 1.00 & 1.00 & 1.00 & 1.00 \\
\hline Wheat offal & 5.30 & 5.30 & & 5.30 & 5.30 & 5.30 & 5.30 \\
\hline Limestone & 1.50 & 1.50 & & 1.50 & 1.50 & 1.50 & 1.50 \\
\hline DCP & 2.00 & 2.00 & & 2.00 & 2.00 & 2.00 & 2.00 \\
\hline PKC & 5.50 & 5.50 & & 5.50 & 5.50 & 5.50 & 5.50 \\
\hline Common Salt & 0.25 & 0.25 & & 0.25 & 0.25 & 0.25 & 0.25 \\
\hline Methionine & 0.10 & 0.10 & & 0.10 & 0.10 & 0.10 & 0.10 \\
\hline Lysine & 0.10 & 0.10 & & 0.10 & 0.10 & 0.10 & 0.10 \\
\hline Premix & 0.25 & 0.25 & & 0.25 & 0.25 & 0.25 & 0.25 \\
\hline Total & 100 & 100 & & 100 & 100 & 100 & 100 \\
\hline \multicolumn{8}{|l|}{$\begin{array}{l}\text { Determined } \\
\text { value }\end{array}$} \\
\hline Crude protein & 19.58 & 19.57 & & 19.63 & 19.68 & 19.75 & 19.82 \\
\hline $\begin{array}{l}\text { Metabolizable } \\
\text { energy } \\
(\mathrm{kcal} / \mathrm{kg})\end{array}$ & 2998 & 2998 & & 2998 & 2998 & 2998 & 2998 \\
\hline Ether extract & 4.01 & 4.02 & & 4.01 & 4.03 & 4.05 & 4.06 \\
\hline Crude Fibre & 4.23 & 4.22 & & 4.27 & 4.28 & 4.30 & 4.30 \\
\hline
\end{tabular}

$\mathrm{GNC}=$ Groundnut cake; PKC $=$ Palm kernel cake; $\mathrm{DCP}=$ Dicalcium Phosphate; $\mathrm{SBM}=$ Soya bean Meal 


\section{Efficiency of Centella asiatica (Gotu kola) leaf meal as feed additive}

\section{Weight gain}

Weight Gain $=$ Final Weight - Initial Weight

Average weight gain/ animal $=$

Final weight $(\mathrm{g})$-initial weight in $(\mathrm{g})$

Total number of animal in the group

\section{Feed conversion ratio}

This was obtained by dividing the quantity of total feed consumed by the weight gain.

$\mathrm{FCR}=\underline{\text { Total feed consumed }}$

$$
\text { Weight gain }
$$

\section{Carcass characteristics}

At the end of 49days experimental period, six birds were randomly selected from each treatment, two (2) per replicate for the carcass parameter. The selected birds were starved overnight and their live weights were recorded. Birds were slaughtered by bleeding through the jugular vein the slaughtered birds were plucked and eviscerated manually. Dressed carcass and internal organ such as thigh, drumstick, breast, heart, gizzard and liver were recorded as the percentage of the live weight.

\section{Statistical analysis}

All data were subjected to analysis of variance using Statistical Package for
Social Sciences (version 21) while treatments means were separated using Duncan's multiple range test at $\mathrm{P} \geq 0.05$ level of significance.

\section{Results and discussion}

The effect of Centella asiatica leaf meal on growth performance of broiler chickens at starter and finisher phase is shown in Tables 3 and 4 , significant $(\mathrm{P}<0.05)$ difference was observed in weight gain, feed intake, Survivability and feed conversion ratio. Birds fed with 4\% CALM had the highest weight gain $(1,683.30 \mathrm{~g})$ and feed intake $(3,295.30 \mathrm{~g})$, while the control had the lowest weight gain $(1,466.70 \mathrm{~g})$ and feed intake $(3,107.80 \mathrm{~g})$. Carcass parameters showed significant $(\mathrm{P}<0.05)$ variations across the treatments. Defeathered weight, Eviscerated weight and dressed weight was highest in T4 lowest value was obtained in the control diet. Highest $\%$ weights of thigh and breast muscles were recorded in experimental group. Dietary levels of CALM significantly $(\mathrm{P}<0.05)$ affect gizzard highest weight $(2.60 \%)$ was obtained in T3 and lowest value $(1.70 \%)$ in T4.

Table 3: Growth performance of broiler chickens fed varying level of Centella asiatica at starter phase

\begin{tabular}{llllllll}
\hline Parameters & T1 & T2 & T3 & T4 & T5 & T6 & SEM \\
\hline Initial weight $(\mathrm{g})$ & 80.20 & 80.00 & 80.00 & 80.20 & 80.10 & 80.00 & 0.10 \\
Final weight $(\mathrm{g})$ & $515.00^{\mathrm{c}}$ & $506.00^{\mathrm{c}}$ & $485.00^{\mathrm{d}}$ & $539.00^{\mathrm{a}}$ & $524.0^{\mathrm{b}}$ & $516.00^{\mathrm{c}}$ & 28.80 \\
Total weight $(\mathrm{g})$ & $434.60^{\mathrm{c}}$ & $426.00^{\mathrm{d}}$ & $405.00^{\mathrm{e}}$ & $458.80^{\mathrm{a}}$ & $443.9^{\mathrm{b}}$ & $436.00^{\mathrm{c}}$ & 3.90 \\
Feed intake $(\mathrm{g})^{\text {Daily average weight }(\mathrm{g})}$ & $774.00^{\mathrm{e}}$ & $824.10^{\mathrm{c}}$ & $775.70^{\mathrm{d}}$ & $824.10^{\mathrm{c}}$ & $870.70^{\mathrm{a}}$ & $864.70^{\mathrm{b}}$ & 11.20 \\
Feed conversion $_{\text {Survivability \% }}^{20.30^{\mathrm{ab}}}$ & $20.30^{\mathrm{ab}}$ & $19.30^{\mathrm{b}}$ & $22.00^{\mathrm{a}}$ & $21.10^{\mathrm{ab}}$ & $21.00^{\mathrm{ab}}$ & 0.30 \\
Sa,b,c & $1.50^{\mathrm{c}}$ & $1.60^{\mathrm{bc}}$ & $1.71^{\mathrm{ab}}$ & $1.70^{\mathrm{ab}}$ & $1.80^{\mathrm{a}}$ & $1.74^{\mathrm{ab}}$ & 0.30 \\
& 100.00 & 100.00 & 100.00 & 100.00 & 100.00 & 100.00 & 0.20 \\
\hline
\end{tabular}

Growth performance of broiler chickens fed CALM as feed additives at the starter phase showed that daily weight gain, feed conversion ratio and total weight gain were significant across the treatments $(\mathrm{P}<0.05)$. Birds on T4, T5 and T6 performed better than the control diet and antibiotics supplemented diet. This can be attributed to the ability of the birds to utilize the CALM efficiently. This result agrees with the findings of Ramiah et al. (2014) who reported significance variations in chickens fed Centella asiatica leaf meal, garlic and antibiotics and observed highest weight 
Ajayi, Olumide, Chioma and Ayodele

Table 4: Growth performance of broiler chickens fed varying level of Centella asiatica leaf meal at finisher phase

\begin{tabular}{llllllll}
\hline Parameters & T1 & T2 & T3 & T4 & T5 & T6 & SEM \\
& & & & & & & \\
\hline Initial weight $(\mathrm{g})$ & $515.00^{\mathrm{c}}$ & $506.00^{\mathrm{c}}$ & $485.00^{\mathrm{d}}$ & $539.00^{\mathrm{a}}$ & $542.00^{\mathrm{b}}$ & $516.00^{\mathrm{c}}$ & 4.70 \\
Final weight $(\mathrm{g})$ & $1508.33^{\mathrm{e}}$ & $1516.67^{\mathrm{d}}$ & $1466.70^{\mathrm{f}}$ & $1683.30^{\mathrm{a}}$ & $1575.00^{\mathrm{b}}$ & $1533.30^{\mathrm{c}}$ & 16.70 \\
Total weight $(\mathrm{g})$ & $993.33^{\mathrm{e}}$ & $1010.70^{\mathrm{d}}$ & $981.70^{\mathrm{f}}$ & $1144.30^{\mathrm{a}}$ & $1051.00^{\mathrm{b}}$ & $1017.30^{\mathrm{c}}$ & 13.20 \\
Daily average & $47.00^{\mathrm{e}}$ & $48.10^{\mathrm{d}}$ & $46.70^{\mathrm{f}}$ & $54.50^{\mathrm{a}}$ & $50.00^{\mathrm{b}}$ & $48.40^{\mathrm{c}}$ & 0.20 \\
weight $(\mathrm{g})$ & & & & & & \\
Feed Intake$(\mathrm{g})$ & $2260.00^{\mathrm{d}}$ & $2337.90^{\mathrm{b}}$ & $2332.10^{\mathrm{c}}$ & $2471.40^{\mathrm{a}}$ & $2276.70^{\mathrm{cd}}$ & $2331.00^{\mathrm{c}}$ & 18.0 \\
Feed conversion ratio & 1.60 & 1.60 & 1.80 & 1.60 & 1.60 & 1.60 & 0.90 \\
Dressing out \% & $76.30^{\mathrm{b}}$ & $77.70^{\mathrm{a}}$ & $75.60^{\mathrm{bc}}$ & $77.30^{\mathrm{a}}$ & $75.00^{\mathrm{c}}$ & $76.30^{\mathrm{b}}$ & 0.20 \\
Survivability & $96.70^{\mathrm{a}}$ & $96.70^{\mathrm{a}}$ & $93.30^{\mathrm{b}}$ & $93.30^{\mathrm{b}}$ & $96.70^{\mathrm{a}}$ & $96.70^{\mathrm{a}}$ & 0.30 \\
\hline a,b,c means within a row with difference superscripts are significantly different $(\mathrm{P}<0.05)$ & & &
\end{tabular}

Table 5: Carcass characteristics of broiler chickens fed varying level of Centella asiatica leaf meal

\begin{tabular}{llllllll}
\hline Parameters $(\mathrm{g})$ & $\mathrm{T} 1$ & $\mathrm{~T} 2$ & $\mathrm{~T} 3$ & $\mathrm{~T} 4$ & $\mathrm{~T} 5$ & $\mathrm{~T} 6$ & SEM \\
\hline Live weight & $1508.30^{\mathrm{e}}$ & $1516.70^{\mathrm{d}}$ & $1466.70^{\mathrm{f}}$ & $1683.30^{\mathrm{a}}$ & $1575.00^{\mathrm{b}}$ & $1533.30^{\mathrm{c}}$ & 37.90 \\
Bled weight & $1435.00^{\mathrm{e}}$ & $1445.30^{\mathrm{d}}$ & $1383.30^{\mathrm{f}}$ & $1597.30^{\mathrm{a}}$ & $1498.70^{\mathrm{b}}$ & $1454.30^{\mathrm{c}}$ & 37.30 \\
Defeathered weight & $1361.70^{\mathrm{d}}$ & $1373.30^{\mathrm{c}}$ & $1300.00^{\mathrm{e}}$ & $1510.70^{\mathrm{a}}$ & $1422.00^{\mathrm{b}}$ & $1374.30^{\mathrm{c}}$ & 36.90 \\
Eviscerated weight & $1150.70^{\mathrm{d}}$ & $1179.00^{\mathrm{b}}$ & $1108.30^{\mathrm{e}}$ & $1302.30^{\mathrm{a}}$ & $1176.00^{\mathrm{bc}}$ & $1170.30^{\mathrm{c}}$ & 32.90 \\
Dressed weight & $995.00^{\mathrm{d}}$ & $1009.70^{\mathrm{b}}$ & $953.00^{\mathrm{e}}$ & $1118.30^{\mathrm{a}}$ & $1008.70^{\mathrm{b}}$ & $1031.70^{\mathrm{c}}$ & 27.70 \\
cut part & & & & & & & \\
Breast (\%) & $30.00^{\mathrm{b}}$ & $31.90^{\mathrm{a}}$ & $26.00^{\mathrm{c}}$ & $31.70^{\mathrm{a}}$ & $26.30^{\mathrm{c}}$ & $29.10^{\mathrm{ab}}$ & 0.70 \\
Thigh (\%) & $16.60^{\mathrm{b}}$ & $14.50^{\mathrm{cd}}$ & $15.60^{\mathrm{bc}}$ & $13.00^{\mathrm{d}}$ & $18.40^{\mathrm{a}}$ & $15.50^{\mathrm{c}}$ & 0.50 \\
Drumstick (\%) & $15.80^{\mathrm{b}}$ & $15.50^{\mathrm{bc}}$ & $15.40^{\mathrm{c}}$ & $14.20^{\mathrm{d}}$ & $16.80^{\mathrm{a}}$ & $15.50^{\mathrm{bc}}$ & 0.30 \\
Wings (\%) & $12.90^{\mathrm{b}}$ & $12.50^{\mathrm{c}}$ & $11.50^{\mathrm{d}}$ & $12.50^{\mathrm{c}}$ & $13.60^{\mathrm{a}}$ & $12.50^{\mathrm{c}}$ & 0.20 \\
Internal Organ & & & & & & \\
Gizzard (\%) & $1.80^{\mathrm{b}}$ & $2.00^{\mathrm{b}}$ & $2.60^{\mathrm{a}}$ & $1.70^{\mathrm{b}}$ & $1.80^{\mathrm{b}}$ & $1.80^{\mathrm{b}}$ & 0.10 \\
Intestine (\%) & 5.30 & 4.90 & 5.70 & 5.00 & 6.00 & 5.80 & 0.20 \\
\hline a,b,c means within a row with difference superscripts are significantly different (p<0.05) & & &
\end{tabular}

gain in broiler chickens fed CALM, Seyed et al. (2013) also observed the effect of four medicinal plant and flavomycin on broiler chickens but in contrast observed highest weight in chicken fed flavomycin (antibiotics). Findings support the report of Farhad et al. (2011) who observed significant $(\mathrm{P}<0.05)$ difference in growth parameters of Ross-304 broiler chickens fed different medicinal plant blend. Maidala et al. (2017) also observed higher values in growth parameters in Anak-2000 fed Moringa oleifera. Alagbe (2019) also observed higher value in growth parameters of Ross-308 fed CALM. The highest weight observed in T4 affirm the claim of effectiveness of phytogenic feed additives as growth promoter. Debnath et al. (2014). Value obtained for dressing out percentage in this study ranged from 75.0$77.7 \%$ the highest dressing out percentage was observed in T2 and lowest was observed in T5. Values obtained in this study was higher than the value of 68.60$73.40 \%$ obtained by Olumide et al. (2018) and lower to the value of $77.33-83 \%$ by Akpodiete (1997) and higher than the recommended value of $60.30-74.65 \%$ by Bamgbose et al. (1998). It can be concluded that the dressing out percentage of broiler chicken fed CALM was within the appreciable recommended value. Carcass yield is an indication of the quality and utilization of the ration (Bamgbose et al., 1998). Broiler chickens fed 4\% CALM showed superior record in live weight, defeathered weight, eviscerated weight and dressed weight compare to $\mathrm{T} 1$ and $\mathrm{T} 2$. Pongmanee (2003) also observed similar result in broiler chicken fed $0.4 \mathrm{~g} / \mathrm{kg}$ crude extract of Centella asiatica. Portugaliza et al. (2011) observed similar result in broiler 


\section{Efficiency of Centella asiatica (Gotu kola) leaf meal as feed additive}

chicken fed varying concentrations of aqueous leaf extract of Moringa oleifera and obtained significant $(\mathrm{P}<0.05)$ difference in all the treatment compare to the control diet. The high body weight obtained at $4 \%$ inclusion level of CALM showed that phytogenic feed additives (PFA) improve feed efficiency and growth rate. The breast part constitute the larger percentage of the animal muscle breast cut showed significant $(\mathrm{P}<0.05)$ variation across the treatment with treatment $\mathrm{T} 2$ having the largest value of $31.9 \%$ and lowest value of $26.0 \%$ was obtained in $\mathrm{T} 3$ Value obtained from this study ranged from 26.0-31.9\%. Value obtained in this study was similar to the value of $28.08-29.43 \%$ obtained by Olumide et al. (2018) who fed broiler chicken with varying level of Ocimum gratissimum. Drumstick, thigh, wings showed significance $(\mathrm{P}<0.05)$ variations highest percentage of thigh was observed in T5 and lowest value was obtained in T4. According to Koreleski et al. (2007) higher carcass yield was also recorded by the addition of aqueous extracts of coneflower, thyme, Nigella sativa in feed. Marcinčák et al. (2011) observed similar observation in breast and thigh muscle weight of chicken fed phytogenic feed additives. The effect of the treatment diets on visceral organs of broiler chickens fed Centella asiatica leaf meal. Gizzard values obtained in this finding showed significant $(\mathrm{P}<0.05)$ value ranged from 1.8$2.6 \%$ the highest value was obtained in T3 and lowest value in control diet. Gizzard is a special part of the internal organ that is well appreciated by the consumer and command good price. It can be inferred that gizzard of chicken fed with Centella asiatica at $0.3 \%$ can be of good economic value to the farmer. The impact of dietary treatments on intestine showed no significant $(\mathrm{P}>0.05)$ variations across all the treatments with T5 having the highest value of $6.0 \%$ and $\mathrm{T} 2$ having the lowest value of $4.9 \%$ This might be related to the antinutritional factor in the leaf meal causing an increase in weight of internal organ during digestion.

\section{Conclusion}

The study has shown that Centella asiatica leaf meal improved feed utilization, carcass quality, growth performance of broiler chickens at 4\% inclusion level without any detrimental effect on the birds.

\section{References}

Alagbe, J. O. 2019. Effects of Dried Centella Asiatica Leaf Meal as a Herbal Feed Additive on the Growth Performance, Heamatology and Serum Biochemistry of Broiler Chicken Int JAni Res

Alcicek A., Bozkurt M. and Abuk, M. C. 2004. The effect of a mixture of herbal essential oils, an organic acid or a probiotic on broiler performance. South African Journal of Animal Sciences, 34 (4): 217-222.

Amerah, A. M., Ravindran, V. and Lentle, R. C. 2009. Influence of insoluble fibre and whole wheat inclusion on the performance, digestive tract development and ileal microbiota profile of broiler chickens. British poultry science, 50, 366-375.

Bozkurt, M., Kucukyilmaz, K., Catli, A.U and Cinar, 2008. Growth performance and slaughter characteristics of broiler Chicken fed with antibiotics, mannan Oligisaccharide and extra oligosaccharide supplemented diets. Int.J. poult.Sci 7(10): 969977.

Banjoko, O. J., Olumide., M. D., 
Oladipo, T. A. and Ajayi, O. A. 2018. Anticoccidial effects of Dietary vernonia amygdalina leaf meal in broiler chicken production Nig J Animal Prod, 45(3), 282-289.

Bamgbose, A. M. and Niba, A. T. 1998. The Nigerian livestock industry in the $21^{\text {st }}$ century $3^{\text {rd }}$ annual conference of Animal Science Association of Nigeria (ASAN) pp 84- 87

Ciftci, M. T., Guler, B., Dalkili, C. and Ertas, O. N. 2005. The effect of anise oil (Pimpinella anisum L.) On broiler performance. Int. J. Poult. Sci. 4:851-855.

Cox, D. N., Rajasuriya, S., Soysa, P. E., Gladwin, J. and Ashworth, A. 1993. Problems encountered in the community based production of leaf concentrate as supplement for pre-school children in Sri-Lanka. International Journal of Nutrition and Food Sciences, 44, 123-132.

Debnath, B. C., Choudhary, K. B. D., Ravikanth, K., Thakur A., and Shivi, M. 2014. Comparative efficacy of natural growth promoter (av/agp/10) with antibiotic growth promoter on overall growth performance and intestinal morphometry in broiler birds. Int Journal Pharm Sci and Health CareIssue 4(2): 155-168

Denli, M., Okan, F. and Celik, F. 2003. Effect of dietary probiotic, organic acids and antibiotic supplementation to diets on Broiler performance and carcass yield. Parkistan journal of nutrition 2(2):89-91

Farhad, K. Ghorbanali, S. Ahmad, K. and Asaad, V. 2012. Evaluation of different medicinal Plants blend in diets for broiler chickens. $J$ Med Plants Res Vol. 5(10), 1971-1977
Huda-Faujan, N., Nonhatn, A., Norrakiah, A. S. and Babji, A. S. 2007. Antioxidant activities of water extracts of some Malaysian herbs. ASUAN Wood Journal, 14, 61-68.

Hashim, P. 2011. Centella asiatica in food and beverage applications and its potential antioxidant and neuroprotective effect. Int Food Research Journal, (18)1215- 1222

Koreleski, J. and Swiatkiewicz, S. 2007. Dietary supplementation with plant extract, xantophylls and synthetic antioxidants: effect on fatty acid profile and oxidative stability of frozen stored chicken breast meat. J Anim feed Sci 16:463-471

Lewis, W. H. and Elvin- Lewis, P. F. 1977. Medical botany: plants affecting main's health. New $\quad y$ or $k$ : John wiley-Int.pub pp 231-232

Maidala, A., Mahmud, M. and Musa, S. 2017. Growth Performance and Cost Benefit Analysis of Broiler Chickens Fed Phytogenic Feed Additives in a Semi-Arid enviroment of Bauchi State, Nigeria Res Journal Pure Sci and Tech 1(1), 42-49

Marcinaic, S., Popella, P., Zdolec, N., Marto, Nova, M., Simkova, J. and Marcincakova, D. 2011. Effect of supplementation of phytogenic feed additives on performance parameters and meat quality of broiler chickens. Slov. Res 48: 27-34

Mohd Ilham, A. 1998. Opportunities on the planting of medicinal and herbal plants in Malaysia. Planter, 74, 339-342.

Olumide, M. D. and Akinola, A. S. 2018. Effect of scent leaf meal (ocimum 
gratissium) supplementationon performance carcasss and meat quality of broiler chicken. Nig $J$ animal prod 2018, 45(3):228-236

Pongmanee, K. 2003. Effect of Asiatic pennywort (centella asiatica 1. urban) leaves a replacement for of antibiotics, on growth, performance, mucosal enzyme activities of small intestine and nutrient digestibility in broiler chicken.

Portugaliza, H. P. and Fernandez, J. R. 2011. growth performance of Cobb broilers given varying concentration of malunggay (moringa oleifera Lam) $J$ of Ani Research and feed research 2(6)465-469
Ramiah, S. K., Idrus, Z., Nordiana, A. A., Mahdi, E. and Goh, Y. M. 2014. Effects of two extracts and virginiamycin supplementation on growth performance, intestinal Microflora Population and fatty acid composition in broiler chickens Asian Australs J. Anim.sci 27(3),375-382

Seyed, D., Sharifi, Saeedeh, H., Khorsandi1, Ali, A., Khadem, A. S. and Hamidreza, M. 2013. The effect of four medicinal plants on the performance, blood biochemical traits and ileal microflora of broiler chicks $J$. Veterinarski arhiv 83 (1),69- 80.

Received: $9^{\text {th }}$ October, 2019 Accepted: $17^{\text {th }}$ January, 2020 